\title{
Occupy and TEA Party's Attention Support Current Relevance of Smith, Hamilton, and Keynes Economic Views President Obama's Economic Influences
}

\author{
Harry Russell \\ Southern University at New Orleans, USA
}

Copyright $(2017$ by authors, all rights reserved. Authors agree that this article remains permanently open access under the terms of the Creative Commons Attribution License 4.0 International License

\begin{abstract}
This article aims to address the relevance of current public and political movements in relationship to America's economic philosophical views and outcomes as reaction to President Obama's Economic Recovery Plan. The discussions take into account the views of varying segments of the population as expressed through the actions and opinions of the Occupy and Tea Party Movements. Connections between economic views and theories of Adam Smith, Alexander Hamilton, And John Keynes and economic principles of these two movements in relationship to the President's theoretical plan are presented. A look into the roles of liberalism, conservatism, and plutocracy are considered as part of the ideological discourse of various segments of the American populous. Views of the government bailout and other stimulus plans introduced by the Administration are explored in relationship to the views held by the two competing movements and the competing political ideologies. The outcome of which is that the President's plan is more closely aligned with the concerns of the occupy movement, Keynesian economic policy theory, and liberalism.
\end{abstract}

Keywords Economic Views, Occupy Wall Street, TEA Party, Social action, U.S. Economic Plan

\section{Introduction}

Preceding the massive global public demonstrations, Elizabeth Warren, although not an expert in economic policy, championed the cause of the liberal position which has become somewhat of the philosophy and effectively the ideology of the Occupy Wall Street movement whose slogan is "We are the 99 percent". These are the common working classes of people across the western world who seeks redistribution of wealth along with greater domestic investment and interest in their economic conditions. The website of the occupy Wall Street loosely organized and to some degree chaotic movement, says it is motivated and patterned after the non-violent protest and demonstrations which occurred in several Northern Africa and Middle East nations. According to the New York Times, protesters references of the " 1 percent refers to the haves: that is, the banks, the mortgage industry, and the insurance industry. The 99 percent refers to the have-nots: that is, everyone else." In other words, said a group member: "1 percent of the people have 99 percent of the money" (1), A study conducted by Blender and Zandy, which studied the impact of large scale government intervention on stimulus found a large fraction of the top 1 percent's gains have actually gone to an even smaller group, the top 0.1 percent — the richest one-thousandth of the population ${ }^{(2)}$.

Because the 1percent is as much the focus as the 99 percent during this discourse, and moreso, the top 0.1 percent, who are described in Blender and Zandy's study ${ }^{(3)}$ in the following manner: Very few of them are Steve Jobs-type innovators; many of them are corporate bigwigs and financial movers-shakers wheeler-dealers. One recent analysis found that 43 percent of the super-elite are executives at nonfinancial companies, 18 percent are in finance and another 12 percent are lawyers or in real estate. And these are not professions in which there is clear relationship between one's income and his/her economic contribution ${ }^{(2.2)}$, descriptions were necessary to provide clarity with regard to who protesters are addressing. With regards to the 99 percent, the recently formed TEA Party stand as the polar opposite to the Occupy protesters and the Tea party strongly advocate for extreme Laissez-Faire. Further, in contrast to the 99 percent protesters, Tea party members and supporters advocate for plutonomy and stand in stark opposition to the Obama Administration recovery plan.

Elizabeth Warren, U.S. Senate candidate, oration regarding the state of taxation in America, which focused on the reality of unequal, and inequitable distribution of wealth was, perhaps long overdue. Ms. Warren's statement that "there is no one in America who got rich on his own", is not a 
new statement among liberal economic philosophers and lower economic classes, but rarely have someone of political prominence publicly articulated it so plainly and clearly, regardless of their level of knowledge pertaining to economic policy. This statement in large part reflects the sentiments of the Occupy Wall Street protesters. "Occupy Wall Street is a leaderless resistance movement with people of many colors, genders and political persuasions. "The one thing we all have in common is that "We Are The 99\%" that will no longer tolerate the greed and corruption of the $1 \%$ " (4). The 99 percent protesters of the Occupy movement argue that public infrastructure along with U.S. commerce resources are developed using taxes generated largely from the middle working classes, which has been echoed repeatedly by President Obama and his administration. As laborers of U.S. infrastructure and as a financial donor adding to the commerce resources, middle and low socioeconomic class workers through the provision of taxes, makes it possible for the elitist $1 \%$ operators of the private industries trading on Wall Street to have their products available to the global free market. The resulting revenue pay enormous corporate profits and individual dividends, but little or none are paid forward or redistributed toward general public interests. However, the $99 \%$ Occupy protesters believe that monetary profits obtained should be, in some measure, shared with the general public, since it is upon their backs that such staggering profits are possible.

\section{Methodology}

The author assessed multiple documents related to the historic information relative to variables of US economic views and theories, ideological positions of Occupy Movement and TEA Party, and, finally, the theoretical basis of President Obama's economic planning. Then established the similarities and differences between economic philosophical views and ideological positioning, followed identification of most cited common attributes, economic philosophy/theory and ideology of the groups targeted in this article. Relative information was then used to establish the relationship to the Obama Administration Economic Recovery Plan and its alignment to the economic theories discussed and response to the social actions taken by the Occupy and TEA Party movements.

\section{Results}

In light of what is described, by the 99percent supports, as avarice greed of pompous libertarian ideology produced by capitalism, the need for Keynesian like approaches may indeed be necessary, as only government, who in part created this free-market capitalist ideology, can intervene in such a way forcing the controlling $1 \%$ to participate equitably in redistributing wealth and thereby support the general welfare. When an individual of the privileged group fails to recognize and compensate the contributions of other segments of the community toward their individual success, other social ills either arise or are made more visible. It beckons the retort of Marie Antoinette, "Let them eat Cake" in light of the peasants having no wheat to make bread. Such things as class distinctions, unemployment, poverty, foreclosures, underfunded education and health services become prominent features of public debate in the midst of such elitist arrogance. Carl Marx noted that "Under capitalism, the proletariat, the working classes ... own only their capacity to work; they have the ability only to sell their own labor. ... a class is defined by the relations of its members to the means of production". Marx continues, under capitalism, the workers, in order to support their families are paid a bare minimum wage or salary. The worker is alienated because he has no control over the labor or product which he produces ${ }^{(5)}$. This alienation can lead to economic problems and generate hostility toward both the government and the wealthy power elite. Marx stated an increasing immiseration of the proletariat occurs as the result of economic recessions; these recessions result because the working class is unable to buy the full product of their labors and the ruling capitalists do not consume all of the surplus value. A proletariat or socialist revolution must occur ${ }^{(5.2)}$. As what have been witnessed across America and the rest of the developed world, large groups of Wall Street protesters comprised of working class and college students, for whom a forward payment would support as the cost of a college education continues to increase, are engaging in social action activities against elitist corporations and individuals. Protesters are demanding government to take action promoting domestic household economic growth for the good of the economy. Change is called for as a result of widespread economic suffrage among working classes and the poor.

There is an ongoing debate between mainstream (or "liberal") economists and conservative/Libertarian/free market economists regarding what economic history tells us about spending during recessions. But the data appears to tell us that spending is sometimes needed in order to help stimulate an economy where demand is below what's needed (because businesses tend to hold onto their money during economic downturns) ${ }^{(6)}$. When Mr. Will, in retort to Ms. Warren, asserts that individual sovereignty zones are not respected, he overstates the position posed by Ms. Warren, who further stated "... God bless, and keep a big hunk of it. But part of the underlying social contract is you take a hunk of that and pay forward for the next kid who comes along" (7). Her statement implies that the individual is entitled to a large share but is obligated through the social contract to apply a sufficient portion of the gains toward the sustainment and future of the Union. Pat Fleck of Citigroup states a position held by many of the $99 \%$ protesters, that being, "I have no problem with people making the most of their available opportunities and becoming rich, evenly astonishingly so. I only care that we have fair playing fields, and a government that is not in the hip pocket of a few" ${ }^{(8)}$. Mr. Will asserts a 
position of individualism as exclusive elitism. In fact, his position can be viewed as Plutocracy. An excerpt from a CitiGroup report, Fleck sites protesters position as: "Our thesis is that the rich are the dominant drivers of demand in many economies around the world (the US, UK, Canada and Australia). These economies have seen the rich take an increasing share of income and wealth over the last 20 years, to the extent that the rich now dominate income, wealth and spending in these countries. Asset booms, a rising profit share and favorable treatment by market-friendly governments have allowed the rich to prosper and become a greater share of the economy in the Plutonomy countries" ${ }^{(8.2)}$ This position invokes feelings of oppressive conditions brought on by the economic power elite and government. Invoking a quote from Paulo Freire, a Brazilian philosopher and educator, "The oppressors do not perceive their monopoly on having more as a privilege which dehumanizes others and themselves. They cannot see that, in the egoistic pursuit of having as a possessing class, they suffocate in their own possessions and no longer are; they merely have". ${ }^{(9)}$

When a government seeks to protect the interest of the industries of the wealthy at the expenses of the very people who manufactured the products and also pay taxes for public infrastructure used to get the product to market, it can seem to be an act of oppressive discrimination to only protect the wealthy. Many of today's elite are of so-called "old money", implying that the accumulation of wealth largely occurred early on in Americans and America's pursuit of the capitalistic ideal of wealth. Slave labor accounted for the majority of labor which generated enormous wealth for individual families; as well as early American use of child labor and menial pay for immigrant and women sweat factory workers. In other words, there are no self-made people because we are all part of a society that contributes to the success of others, whether willingly or forced by government taxes and regulations. Accomplished people benefit from advantages created by earlier generations ... and by the simple fact that they live in a country that provides opportunities that are not available everywhere. The successful, thus, owe quite a lot to the government and social structure that made their success possible ${ }^{(10)}$.

The protective right wing seeks to limit government intervention seemingly for the benefit of avoiding the Preamble phrase of "...promotion of the general welfare..."Government tax incentives for their corporations and tax breaks on personal income taxes reduces the forward payment to the next "kid" spoken of by Ms. Warren, and reduces payments toward the common good of the people. Result is the working class experience tax increases to offset the breaks granted to the individual elite, which is not nearly enough to cover cost associated with public health, welfare and education. Laissez-faire practices have not prevented private interests from turning to the government for help on numerous occasions, however. Railroad companies accepted grants of land and public subsidies in the 19th century. Industries facing strong competition from abroad have long appealed for protections through trade policy. American agriculture, almost totally in private hands, has benefited from government assistance. Many other industries also have sought and received aid ranging from tax breaks to outright subsidies from the government (US Department of State). It seems evident that the $1 \%$ views the national government system as a plutocracy and has evolved behaviors of the egoistic monarchist of early mercantile Europe, seeking to control availability of needed resources such as clean water and suppressing minimum wage rates. Paulo Freire stated "As long as they live in the duality in which to be is to be like, and to be like is to be like the oppressor, this contribution is impossible." The contribution Freire speaks of is liberation, and in the US case, the liberation from exclusive individualism to an individual promotion of "We the People of the United States, in Order to form a more perfect Union, establish Justice, insure domestic Tranquility, provide for the common [defence], promote the general Welfare, and secure the Blessings of Liberty to ourselves and our Posterity..." (U.S. Constitution, Preamble). Occupy Wall Street protesters are correct for calling for government spending and intervention to stimulate the economy and to force equity in taxation, as only this Keynesian approach can produce the required level of economic change. Another point of disagreement between liberal and free market proponents is the effects of top marginal tax rates on the top earners. Free market proponents generally argue that lowering taxes on the top earners frees up their money and encourages them to put it to more productive use, which is reinvested into the economy and in fact yields even more tax revenue (because the increased production will yield enough tax revenue to offset the lowered tax rate, creating even more tax revenue) (6.1). Nothing can be further from the truth as pointed out by Cloud when he states, It would be a mistake to think that Bill Clinton's tax increase or Reagan and Bush's second tax cuts caused the increased revenues that followed, or that Bush's first tax cut caused the drop in tax revenues that ensued ${ }^{(6.3)}$.

The idea of false consciousness, posed by the herd of liberal intelligencia, seems to not only pertain to the malleable herd of Americans but would also apply to the conservative libertarian right wing. False consciousness rests in the belief that the economy will right itself without government intervention and that government spending on domestic job creation is not the way out of the recession. In the "Affluent Society", John Kenneth Galbraith "asserts that the conventional wisdom of economic thinking in the United States is based in nineteenth-century European economic theory and is no longer suited to the unprecedented phenomenon of mass affluence achieved by American society in the twentieth century. He criticizes the overemphasis on high rates of production as a measure of economic prosperity and suggests that other factors may be of greater importance" (11). The response to the economic disaster left behind by years of market deregulation and unchecked corporate greed can be characterized in two parts: fiscal stimulus (direct spending and tax cuts by the 
government), and financial stabilization measures (stabilizing banks and the financial system as a whole, such as TARP and Fed actions). Both of these are viewed as crucial parts working in tandem ${ }^{(2.3)}$.

The results of the study conducted by Blinder and Zandy $^{(3.2)}$ reveals the effects of the fiscal stimulus alone appear very substantial, adding almost 2.7 million jobs increasing the 2010 GDP by about $3.4 \%$, while holding the unemployment rate about 1.5 percentage points lower.

The lion's share of the fiscal stimulus of course was the American Recovery and Reinvestment Act passed over almost unanimous Republican objections last year. The total cost of fiscal stimulus (direct spending or tax reductions) amount to about $\$ 1.07$ trillion so far ${ }^{(2.4)}$. The current recession and corporate bailouts that have done little in the way of stimulating the economy nationally or globally substantiates that more need to be done other than reliance on production and sales rates of corporate elites to relieve the recession. Without the government's response, GDP in 2010 would be about $11.5 \%$ lower, payroll employment would be less by some 8.5 million jobs, and the nation would now be experiencing deflation ${ }^{(3.3)}$.

Summarizing findings of Blinder and Zandy's report reveal that cutting taxes on corporations and unearned income (capital gains) prove to be the worst stimulative measures, while spending on entitlements such as food stamps, direct federal assistance for jobs and unemployment benefits prove to be the best stimulative spending measures. For example, every dollar spent in unemployment benefit generates over 5 times the economic activity as every dollar of Bush tax cuts. There is no doubt that only fiscal stimulus measures can directly put people to work or deliver money in the pockets of those who need it (in the form of unemployment insurance, for example $)^{(2.5)}$. This implies that the measure of economic prosperity is more about the prosperity of all of the citizens rather than only on the $1-2 \%$ of individuals controlling America's wealth. Thus, in order for those individuals to remain economically successful there must be tax reform, government intervention/spending on job creation, home mortgage assistance, and other such modern indicators of economic prosperity. Stimulating the proletariat ability to afford basic needs and discretionary income to purchase more goods and services provided by corporate America would likely be more productive at stimulating the economy rather than simply going with the old status quo. Warren is making a very direct argument when she stated:

"Without the enabling framework that only government can create, individuals cannot securely enjoy the fruits of their endeavors. Every return on investment, then, is actually a return on two sources of investment, one reflecting individual choice, the other public decisions. Taxation is not theft; nor is it, as the late philosopher Robert Nozick once put it, "on a par with forced labor." Rather, it reflects the return on the public investment to which nearly everyone contributes. It does not rest on the claim that all resources are collective and that individuals receive what is theirs as an act of grace, but rather on the more modest claim that we all owe something in return for the collective goods without which our individual striving cannot succeed ${ }^{(12)}$.

Now to be clear, those who believe what 99 percenters and Ms. Warren advocates are not purporting that the U.S. is headed toward a socialist movement, rather they seem to be suggesting that a different approach to economic prosperity should be pursued. Michael Gerson of the New York Post points out in his article "Focus less on income equality, more social mobility" that both conservatives and liberals are, in part, correct in their positions on economic changes. Conservatives are correct that tax increases on the wealthy to fund entitlement commitments that go mainly to the elderly would do precious little to address this problem. Liberals are right that a combination of rising economic inequality (even if the rise is gradual) with stalled economic mobility is a recipe for destructive social resentments. Americans will accept unequal economic outcomes in a fair system. They object when the results seem rigged ${ }^{(13)}$.

A huge factor of contention raised by the Occupy protesters rest in the call for recognition of support for individual property rights, in that they ask to be taxed less and afforded well-paying jobs so that they may be able to acquire property or not foreclose on property owned; and they are calling on government to protect their individual freedom and liberties through creating fair taxation and employment opportunities as provided for the wealthiest of society. Nobel Laureate Vernon Smith as did Adam Smith recognized the importance of individual freedom and property rights as being significant parts of moral human behavior towards each other. Individuals with full ownership of their life, liberty and property judge themselves, and they care about the positive judgments of others. This accountability is the moral basis that binds a community, allows for cooperation, and enables human prosperity ${ }^{(14)}$. More specifically Kibbe quotes Adam Smith, "The most sacred laws of justice, therefore, those whose violation seems to call loudest for vengeance and punishment, are the laws which guard the life and person of our neighbour; the next are those which guard his property and possessions...". This statement taken in context of Elizabeth Warren and President Obama's position seems to beckon that all Americans provide their fair share to help protect life, person, property and possessions of all citizens now and the future.

Groups such as the TEA party, who advocates for non-Keynesian policies, have found Adam Smith's statement to be a corner stone for their position of less government intervention. Kibbe ${ }^{(14.2)}$ states "From this "sacred law," comes the Tea Party's righteous indignation with bailouts and deficit spending (paid for with other people's stuff) and other government intrusions on our lives, such as Obamacare's mandate dictating to every American what health insurance we must buy and which treatments we may or may not be allowed to have. Every policy we oppose can be characterized as forcing the responsible to subsidize the irresponsibility of others, an inversion of individual responsibility". Yet this view stops short of citing the 
concern is not guarding life, person, property and possessions for all citizens but rather only the privileged, wealthy classes, banks, insurance companies and global trading firms. So, it is clear that interpretation of guiding economic principles, as indicated between the two Smith's views, may serve to further polarize socioeconomic groups.

A different approach or view must be considered, a recent super-committee of US legislators, comprised of 6 republicans and 6 democrats, a bi-partisan committee charged with development of equitable legislation to jump start economic recovery on both fronts, domestic and foreign trade. Another possible approach which, as Galbraith exposed is central to concerns in reassessing the American economy include: the nature of American affluence; the relationship between production, consumption, and advertising; the abiding issue of poverty and economic inequality; and changing factors in such economic concerns as employment, inflation, and consumer debt ${ }^{(11.2)}$. These have all become concerns associated with the Occupy protesters. Galbraith further advocates a greater emphasis on sales tax over property tax; greater government expenditure on such public services as education and health care; and a national goal of expanding the "new class" of citizens able to pursue work they find inherently enjoyable ${ }^{(11.3)}$. American history has seen the pendulum swing repeatedly between laissez-faire principles and demands for government regulation of both types. For the last 25 years, liberals and conservatives alike have sought to reduce or eliminate some categories of economic regulation, agreeing that the regulations wrongly protected companies from competition at the expense of consumers. Political leaders have had much sharper differences over social regulation, however. Liberals have been far more likely to favor government intervention that promotes a variety of non-economic objectives, while conservatives have been more likely to see it as an intrusion that makes businesses less competitive and less efficient ${ }^{(15)}$.

So, it can be argued that if conservative libertarians continue to hold firm to false consciousness, and oppose the Obama Administration's jobs plan and other domestic stimulus efforts proposed by democrats and bipartisan committees, then the American people particularly those espousing economic equity, such as the Occupy Wall Street, $99 \%$ protesters, will continue to experience economic decline at home and abroad.

The liberal position posed by Adam Smith in 1776, that "By restraining, either by high duties, or by absolute prohibitions, the importation of such goods from foreign countries as can be produced at, home, the monopoly of the home market is more or less secured to the domestic industries employed in producing them", is one of several points that remain relevant in contemporary national economic discussions. In the free trade world, the US, in order to ensure continued domestic revenue for its produce, must impose tariffs on imported produce which replicates domestic produce. The US must intervene in effort to sustain as near a monopoly as possible for goods and services born of individual US citizens and perhaps increase domestic revenue, thereby helping sustain national wealth. In some cases, it may be necessary to prevent the importation of such commodities, as a means to increase domestic industries demand, employment, revenue and reliance on domestic supply of such commodities.

Fear of threats to this manner of generating personal and national wealth leads to the republican "...ideological inspiration [that] dovetails with the philosophy of Thomas Hobbes, who predated Adam Smith by a century and who expounded on an amoral philosophy of self-interested individualism, counterbalanced by acquiescence to authoritarianism,"(16). Certainly Smith advocated for the need to allow the individual to endeavor into whatever industry in which a person saw opportunity to fill a needed void and hence make a profit. The personal selection of industry, production of commodities, and the distribution of such commodities yield specific monetary benefit to the individual but also the natural order extends benefits to the country, particularly, when government acts to protect the monopolization of such industries/manufactures within the U.S. and abroad.

Larry Elliott, Economics editor of The Guardian points out "Empires decline for many different reasons but certain factors recur. There is an initial reluctance to admit that there is much to fret about, and there is the arrival of a challenger (or several challengers) to the settled international order. In Spain's case, the rival was Britain. In Britain's case, it was America. In America's case, the threat comes from China" ${ }^{(5.3)}$. The current U.S. economic recession is, in part, due to a failure of bureaucrats, particularly conservatives, to support domestic growth through stimulating and suggests helping to sustain industry growth among its citizens. Europe is wrestling with a debt crisis. Economic growth in powerhouse China appears to be slowing. And in the United States, political paralysis has left policymakers with few tools to fight a slowdown ${ }^{(17)}$.

Over the past twenty years, America has opted to increase importation of staples, such as sugar and corn, as well as high tech and mechanical goods such as computer components, drilling equipment resulting from trade agreements like the North America Free Trade Agreement (NAFTA). NAFTA signed into law by President Clinton (1993) and entered force January 1, 1994, was launched 15 years ago to reduce trading costs, increase business investment, and help North America be more competitive in the global marketplace (Amadeo, 2011). Trade agreements often reduce the tariffs and or remove them totally, making the imported commodity equal in value and in many cases made available in large quantities and at cheaper costs, because it's cheaper to produce in foreign countries. As of January 1, 2008, all tariffs between the three countries [Mexico, Canada, and US] were eliminated. Between 1993 and 2009, trade tripled from $\$ 297$ billion to $\$ 1.6$ trillion ${ }^{(18)}$. The U.S. has been experiencing increased unemployment, reduced gross domestic income, and another recession. President Obama said he would strive to reform the remaining aid package in a 
bid to earn mandatory congressional approval. The President said "My commitment is that we are going to fundamentally change some of the practices in this next stage of the program," Obama said, adding it would focus on creating jobs, aiding small businesses and easing home mortgage foreclosures ${ }^{(18.2)}$, these ideals are purely Smith like in that the focus is on domestic population growth needs.

Kimberly Amadeo in her article entitled, "Causes of Economic Recession", states that economic recessions are caused by a decline in GDP growth, which is itself caused by a slowdown in manufacturing orders, falling housing prices and sales, and a drop-off in business investment. The result of this slowdown is declining employment, and rising unemployment, which causes a slowdown in retail sales. This creates a downward spiral in manufacturing and increased layoffs. Stock market decline, known as a bear market, can be the result of a recession however it is often a cause ${ }^{(18.3)}$. Reluctantly, in 2008 Congress agreed with President Obama's administration to restructure a substantial bailout, known as Troubled Asset Relief Program (TARP), implemented by former President Bush. Bush invoked the Hamilton ideals by choosing to fund several major industries with huge international trade implications, such as the automotive and banking industries. The money from the TARP fund has so far been used to bail out mostly ailing banks and automakers, and insurance and credit card companies, among others ${ }^{(18.4)}$. The Treasury never tapped the full $\$ 700$ billion... it had committed $\$ 470$ billion and disbursed $\$ 387$ billion, mostly to hundreds of banks and later to A.I.G., the car industry - Chrysler, General Motors, the G.M. financing company and suppliers - and to what has been, thus far, a failed effort to help homeowners avoid foreclosures ${ }^{(1.2)}$. In the case of automotive industries, the domestic shortfall came in the way of closing American auto companies or reducing the number and model types made by remaining American Companies, while Japanese and other imports continue to enter the country robing the US domestic producers of monopolizing the industry within their own borders. The banking industry, which is the catalyst for domestic growth, needed an infusion of cash to offset the large national debt incurred from bad business and home mortgage loans, foreclosures, and poor investments at home and abroad. The decline of the dollar in the global market and the pending credit status reduction in the global market, in conjunction with the declining stock market trading of US goods made it very real that government intervention on the part of private industry was necessary in order to stimulate the waning national economy. These circumstances and political reactions to the current economic condition have clear similarities to the position of Adam Smith's view of government supporting private sector domestic growth to serves as a stimulus for national growth.

\section{Conclusions}

However, the conservative congress resisted the notion of bailouts for individuals and private firms as necessary to stimulate the economy. Political bickering is preventing Washington from doing much of anything. Congressional Republicans are focused on cutting government deficits, not widening them in the name of helping the economy. They are resisting President Barack Obama's $\$ 447$ billion plan to generate jobs with payroll-tax cuts and more spending for roads, bridges, schools and other infrastructure projects ${ }^{(17.2)}$. Instead they argue that the focus should be on promoting increased exportation and supporting industries with global ties (Big Business) to stimulate the economy. Associated Press Business Insider ${ }^{(17.3)}$ reported, Frightened Americans would rather cut their debts than borrow, and businesses aren't seeing enough sales to justify hiring and expanding despite rock-bottom borrowing costs. ... That leaves fiscal policy - government spending programs and tax cuts — as the only other way to juice growth. Alan Blinder, Mark Zandy, cited in their article "How the Great Recession Was Brought to an End", that the effects of the fiscal stimulus alone appear very substantial, raising 2010 real GDP by about $3.4 \%$, holding the unemployment rate about 1.5 percentage points lower, and adding almost 2.7 million jobs to U.S. payrolls ${ }^{(3.4)}$. Banking bailout was to provide reduced mortgage interest rates, increasing tax incentives for business development or moving operations back to the US, and raising tariffs on competing goods from foreign countries and low-interest loans made to individuals for home purchase and small business development.

At a time when the US need an infusion of creative ideas, patents, and industries to stimulate personal and national economic growth, Congress seems to be at an impasse with how to proceed in financing a plan that is beneficial to working classes. The 99 percent protesters, though largely unorganized, do seem to have substantial agreement regarding the problem and approach to correcting it. The New York Times report "While the protesters seem united in feeling that the system is stacked against them, with the rules written to benefit the rich and the connected, they are also just as often angry about issues closer to home, like education and the local environment ${ }^{(1.3)}$. Both education and the socioeconomic political environment are critical to the future sustained growth of both the domestic and foreign economies, while ensuring personal development that is translated into national production, willing financial contributors toward the national debt. The reluctance to grow private industry and rely on the status quo, in a time when the US is in need of new domestic goods and resources that can be used in multiple global markets only serve to stifle US economic growth. A large portion of Americans, the $99 \%$, willing to contribute to national economic growth, cannot readily contribute without first obtaining a bank loan to advance their ideas. Because some congressmen view their desire to entrepreneurially compete in the marketplace only as self-serving, and not directed to the greater interest of the nation, such loans should be limited and or not made at all. This attitude and behavior has led to US spending on 
imported goods and services which were once produced or could be produced in larger quantities in the US. Associated Press, Business Insider reports "Economist Eswar Prasad of Cornell University saying the U.S. government should tolerate higher deficits now to spur economic growth - as long as it delivers a credible plan to bring its budget under control in the future". The powerful Chinese economy is supposed to account for a third of global growth this year. Increasingly, other countries depend on China's insatiable demand for raw materials and machinery to give their own economies a lift. The mining towns of Western Australia, for instance, are booming as they fill orders from China for iron, zinc and coal ${ }^{(17.4)}$.

On the other hand, the argument posed by Alexander Hamilton, that a domestic market is greatly to be preferred to a foreign one, because it is in the nature of things, far more to be relied upon ... To secure such a market, there is no other expedient, then to promote manufacturing establishments. Further Hamilton expounds that it is the interest of nations to diversify the industrious pursuits of the individuals who compose them. This view support the belief that a nation must recognize its capacities regarding abilities to manufacture goods and resources, capitalizing on what it has in abundance by directing business interests and supporting pursuits that serve to benefit the national interests. In this way the individual is not in pursuit of entrepreneurial endeavors for the sake of individual profit but because it serves the national interest. Therefore, national interest dictates diversification and to the industries that prove to be advantageous to the US.

Consequently, Hamilton's view purport that "if one nation were in a condition to supply manufactured articles on better terms than another, that other might find an abundant indemnification in a superior capacity to furnish the produce of the soil and a free exchange of the commodities which each was able to supply, on the best of terms, might be carried on between them, supporting in full vigor the industry of each. The U.S Constitution, of which Alexander Hamilton was a major contributor, is a protectionist one.

In a letter to James Duane, Hamilton indicated Congress should have powers, such as "all that relates to war, peace, trade, finance, ....declaring war...laying prohibitions on all the articles of export or imports, imposing duties, granting bounties, and premiums... of regulating trade... coining of money, establishing banks, on such terms, and with such privileges as they think proper, appropriating funds and doing whatever else relates to the operation of finance, transacting everything with foreign nation......and making treaties of commerce" ${ }^{,(19)}$. Former President Bush apparently embraced this ideal, in part, when he first instituted TARP, as he chose to provide the bailout funding to banks, automakers, and insurance companies. Hamilton who was first to propose the idea of a bank of the United States to Robert Morris, stated in the letter to James Duane that a bank should be erected with capital coming from joint credit of the public, monied men, and foreign loans ${ }^{(18.5)}$. Bush's emphasis on banking bailout was predicated on the notion that an infusion of cash would stimulate international banking investments and loans at favorable interest rates to industries, while encouraging exports and increasing taxes on imported products all in effort to reduce national debt.

But, the situation in recent years is such that the US has decreased the exploitation of ideas, resources and developments of the nation. Instead the government has relied on materials and resources that had been in commerce as the nation's produce of interest, as the mainstay of economic growth, but with so many countries offering cheaper substitutes of such goods the demand for US exports of these goods have been significantly diminished. Further, US production of other goods needed to sustain the country that are manufactured in other countries, can no longer be obtained through commodity trade since the goods produced by the US is accessible in their own country or through another at a cheaper cost. This situation renders the US at-risk for incurring debt because it depletes its surplus and now will have to purchase needed goods rather than trade equally needed goods.

Today, the US finds itself indebted to multiple nations, particularly China, who once was one of the largest importers of US products, and now the US is one of the largest importers of Chinese goods. China continues to buy US debt making the US more dependent on their export goods in exchange for debt reduction. Business Insider reports ... any signs the Chinese economy might be slowing are sure to frazzle investors. And a report this week showing that Chinese manufacturing is contracting sent financial markets into a tailspin. Perhaps it shouldn't have been a surprise: China's central bank has been raising interest rates to slow growth and bring inflation under control ${ }^{(17.5)}$.

The TEA party plutocratic view merges with those of Hamilton, when it asserts to protectionism of manufactures and exaggerated laissez-faire would generate revenue, but as we are now experiencing, that is not necessarily the case. This was exemplified following the 2010 mid-term elections, when tea party members and conservative backers "vowed to defund the recently passed Health Care Reform Act, never raise taxes, and cut the federal fiscal budget as much as possible. Some vowed to reduce the federal government to a bare framework. Some were more specific, promising to repeal certain laws (such as the Health Care Act), dismantle government agencies (like the Department of Education, the Environmental Protection Agency, and the Department of Energy), and either restructure or eliminate Social Security, Medicaid, and Medicare"(20) as a means to cutting the federal spending and deficit. Blender and Zandy study, which focuses on the impact of government intervention concludes that they likely prevented a second great depression ${ }^{(2.6)}$; further concludes that "There is no doubt that only fiscal stimulus measures can directly put people to work or deliver money in the pockets of those who need it (in the form of unemployment insurance, for example.) In addition, no one can be blamed for distrusting the CEO's and bankers on Wall Street ${ }^{(2.7)}$. This finding helps validate the protesters, and 
more importantly validates the president's plan for limiting cuts to entitlements, and increased spending on jobs, and expanded unemployment benefits.

A US congressional oversight panel criticized lack of transparency and accountability within the Bush II administration for its handling of the initial bailout fund. The non-partisan panel said it was in the dark about how some ailing banks that received cash infusions were using the money, and blamed the Treasury Department for its apparent failure to ease the home mortgage crisis at the epicenter of the global financial meltdown ${ }^{(1.4)}$. These criticisms provide validity to Blender and Zandy's comment that distrust of Wall Street, mortgage insurers and Bankers are justified but "should not be allowed to cloud our judgments in terms of the huge role our financial system plays in our lives" (2.8).

\section{Comments/Recommendations}

So, it cannot be denied that both economic views of Smith and Hamilton are still, in some aspects, being emphasized if not implemented by means of partisan politics. The debate between the views of Adam Smith and Alexander Hamilton is as relevant today as they were three hundred years ago. Occupy Wall Street protesters and the Obama Administration purporting Smith's basic philosophy toward national wealth and prosperity; and Tea partyers along with conservative republican controlled Congress purporting Hamilton's philosophy. Both views deserve present viable arguments to addressing contemporary conditions affecting the national economic wealth. Adam's view that the government support of private endeavors, regardless of how self-seeking the entrepreneurial purpose, will naturally benefit the national wealth; and Hamilton's idea that the interests of the nation should supersede individual interests in entrepreneurial pursuits, supported by government in monopolizing US exportation of such produced goods that are needed by foreign countries. Both views seek to secure a place in the global economy for the US. However, these views tend to play out as political ideologies that are polar opposites which are used to maintain partisan divisiveness when it comes to resolving current economic issues.

Agreeing with the President's call for bailouts, bi-partisan legislation and subsequent policies, and revision of certain trade agreements and tax laws, it is believed these actions would be helpful measures to addressing the declining economic condition. Finding a means to support private growth through government supported financing (Bailouts, jobs, entitlements, mortgage assistance), is one side of the equation, while the other side is to stimulate business interest in the global market for goods exclusive or nearly exclusive to US manufactures. And while Democrats, by and large, want that super-elite to make at least some contribution to long-term deficit reduction, Republicans want to cut the super-elite's taxes even as they slash Social Security, Medicare and Medicaid in the name of fiscal discipline ${ }^{(15.2)}$. Imposing sizable tariffs on imports that compete with domestic goods as well as redefining trade agreement commodities and their tax rates, simply must occur, along with other domestic tax changes and banking loan policies and practices, if the US is to favorably address current economic conditions, and bring an end to the Occupy Wall Street protests.

Support for a synthesizing of both views, in the natural harmony of things, would suggest that investment into helping minimize foreclosures and reducing inflation and poverty while supporting the business development ideas of private individuals may well lead to a stronger domestic economy and produce commodities exclusive to US manufactures interest. Such newly developed commodities can then be exported as a major part of the US foreign trade for the long term. An article first reported in the New York Times by one of its journalist states:

The New York Times' David Brooks sees an ideological shift for the country coming, and it starts with the enactment of this plan: "... Over the next few years, the U.S. will have to climb out from under mountainous piles of debt. Many predict a long, gray recession. The country will not turn to free-market supply-siders. Nor will it turn to left-wing populists. It will turn to the safe heads from the investment banks. For Republicans, people like Paulson. For Democrats, the guiding lights will be those establishment figures who advised Barack Obama [last week] — including Volcker, Robert Rubin and Warren Buffett."

Brooks continues, ".... We're not entering a phase in which government stands back and lets the chips fall. We're not entering an era when the government pounds the powerful on behalf of the people. We're entering an era of the educated establishment, in which government acts to create a stable and often oligarchic — framework for capitalist endeavor." ${ }^{(21)}$

Presumably the agents for the ideological shift, identified by Brook's, rest in the emerging ideologies of the conservative TEA party movement and from the liberal 99 percent Occupy Wall Street Protesters. The strength of these two opposing ideologies has led to Capitol Hill polarization and more than usual partisan politics. More importantly is that the power of the voices from these groups, in part, gave rise to the Congressional "Super Committee" recently assembled, at the request of the President to come up with an equitable solution to the recession. Although that committee could not reach an agreement over tax changes, they were able to reach agreement on several other major interest areas that were of concern to the protesters and TEA party conservatives. On the Wall Street Protester side, agreement in favor of such things as limiting cuts to education, unemployment benefit extension, spending for jobs and some areas of healthcare occurred; while some of the TEA party issues agreed upon favorably include reducing overall spending and cutting programs, increasing free-trade agreements expanding exporting potential and revenue, among others. It remains to be seen how these things are acted upon since much of the give and take was contingent on whether the $1 \%$ will pay a fair share forward in the form 
of taxes or will the burden be once again imposed upon the $99 \%$.

\section{Acknowledgements}

Southern University and A\&M College, Nelson Mandela School of Public Policy The Southern University at New Orleans, School of Social Work And Special Thanks to my loving wife, Carla and son Antoine.

\section{REFERENCES}

[1] New York Times, (2010). Credit Crisis — Bailout Plan (TARP), http://topics.nytimes.com/top/reference/timestopics/subjects/ c/credit_crisis/bailout_plan/index.html

[2] Peoples View, (2010) Federal Actions on the Economy, and the End of Laissez Faire, http://www.thepeoplesview.net/201 0/08/federal-actions-on-economy-and-end-of.html

[3] Blinder, A, Zandy, M, July 27, 2010; How the Great Recession Was Brought to an End

[4] Occupy Wall St, (2011). Answering Egypt's Call for Solidarity; Occupy Wall Street http://occupywallst.org/

[5] AllAboutPhilosophy.org What is Marxism, 2002 - 2011, http://www.allaboutphilosophy.org/what-is-marxism-faq.htm

[6] Cloud, Cecil J, (2010). The Obama Recession and Economic History; News and Society: Economics Elliott, Larry, Economics editor, The Guardian, (2011). Decline and fall of the American empire, http://www.guardian.co.uk/business/2 011/jun/06/us-economy-decline-recovery-challenges

[7] Madison, Lucy, (2011). Elizabeth Warren: "There is nobody in this country who got rich on his own.

[8] Fleck, Pat, (2010), "Plutonomy"; Citigroup

[9] Paulo Freire quotes, Pedagogy of the Oppressed (1968, English trans. 1970) Ch1; http://www.wikidbs.com/quotes/pa ulo-freire/
[10] Dionne E.J. Jr., (2009); From Elizabeth Warren, the proper case for liberalism; Washington Post, http://www.washingto npost.com/opinions/from-elizabeth-warren-the-proper-case-f or-liberalism/2011/10/09/gIQA5ZZeYL_story.html

[11] eNotes.com. January (2006). Napierkowski, Marie Rose, 1998,"The Affluent Society: Introduction "Nonfiction Classics for Students." Ed.. Vol 3. Detroit: Gale,. 15 October 2011. http://www.enotes.com/affluent-society/introduction

[12] Galston, William, (2011), How George Will Misunderstands Both Elizabeth Warren and Liberalism; The New Republic

[13] Gerson, Michael, (2011). Focus less on income equality, more social mobility; The Muskegon Chronicle

[14] Kibbe, Matt, (2011), What Sets the Tea Party Apart; Human Events: Powerful Conservative Voices; http://www.humanev ents.com/article.php?id=47501

[15] Krugman, Paul, (2011).We Are the 99.9\%, New York Times- Opinion Pages,http://www.nytimes.com/2011/11/25/ opinion/we-are-the-99-9.html? $\mathrm{r}=1 \& \mathrm{ref}=$ occupywallstreetLa issez-faire Versus Government Intervention, From U.S. Department of State, http://EzineArticles.com/

[16] Palen, Marc-William,(2011), The Ideology that Drives the Republican Party

[17] Associated Press-Business Insider, (2011). A Quick Global Tour Of The World's Economic Meltdowns, http://www.busi nessinsider.com/a-quick-global-tour-of-the-worlds-economic -meltdowns-2011-9

[18] AFP, Washington, (2009). Obama promises to reform financial bailout plan, http://www.google.com/hostednews/af p/article/ALeqM5jzIH0vmzB0e1YYHhIUH7ZWGKaH8Q Amadeo, Kimberly,

History of NAFTA, http://useconomy.about.com/od/tradepol icy/p/NAFTA History.htm

[19] Martin, Neil, (2009). Protectionism or Die II: Free Trade Refuted, Larouche Political Action Committee, http://larouchepac.com/node/12019

[20] Relative, Saul, (2011)Note to John Boehner: Tea Party Has Become a Defective Part; Yahoo! Contributor

[21] Brooks, David, 2008, First Read on MSNBC.com, McCain vs. Obama: Bailout politics; The New York Times', http://firstread.msnbc.msn.com/_news/2008/09/23/4433136mccain-vs-obama-bailout-politics 